\title{
ANALYSIS OF THE IMPACT OF SURAMADU BRIDGE DEVELOPMENT TO THE ECONOMIC GROWTH OF ITS CORE AND PERIPHERY REGIONS
}

\author{
Liza Setya Eka Hasul ${ }^{* 1}$ \\ Ari Dwi Jayanti
}

${ }^{1}$ Fakultas Ekonomi dan Bisnis, Universitas Airlangga

${ }^{2}$ Fakultas Ekonomi dan Bisnis, Universitas Airlangga

\begin{abstract}
East Java is one of the provinces in Indonesia which economic growth is above the national average. The city of Surabaya is the biggest contributor to the economy of East Java. Approximately 24\% of the GDRP of East Java comes from this city. Although Bangkalan Regency is one of the bordering regencies of Surabaya, its economic growth is relatively low compared to the other bordering regencies. One of the government efforts to reduce the regional inequality is by building the Suramadu Bridge. According to the polar theory of growth, there are two possibilities that may occur as a result of regional interconnectivity. The first is centrifugal force which drives the population and its activities to move out of the core area followed by relocation of urban sectors and zones. The second is centripetal force which encourages population and activities to move towards the center or core. The objective of this study is to assess the impact of the construction of the Suramadu National Bridge on economic growth in the core and periphery regions. Using Difference-in-Difference method, we found that the impact of the construction of the Suramadu Bridge on economic growth was greater in the periphery area than in the core area. This result might also imply that the development of Suramadu Bridge also resulted in the formation of centrifugal force which encouraged the economy to develop from the core to the periphery.
\end{abstract}

Keywords: Bridge, Core, Growth, Periphery

$J E L: R 1, R 4,04, I 1, I 2$

\section{ABSTRAK}

Jawa Timur merupakan salah satu provinsi di Indonesia yang memiliki rata-rata pertumbuhan ekonomi di atas rata-rata nasional. Kota Surabaya merupakan kontributor terbesar perekonomian Jawa Timur. Sekitar 24\% PDRB Jawa Timur berasal dari kota ini. Meskipun Kabupaten Bangkalan merupakan salah satu kabupaten yang berbatasan dengan Surabaya, namun pertumbuhan ekonominya relatif rendah dibandingkan dengan kabupaten lainnya yang juga berbatasan dengan Surabaya. Salah satu upaya pemerintah untuk mengurangi ketimpangan regional ini adalah dengan membangun Jembatan Suramadu. Menurut teori kutub pertumbuhan, ada dua kemungkinan yang mungkin terjadi akibat interkonektivitas regional. Pertama, gaya sentrifugal yang mendorong penduduk dan aktivitasnya keluar dari kawasan core diikuti dengan relokasi sektor dan zona perkotaan. Kedua, gaya sentripetal yang mendorong penduduk dan aktivitas bergerak menuju pusat atau core. Penelitian ini bertujuan untuk mengkaji dampak pembangunan Jembatan Nasional Suramadu terhadap pertumbuhan ekonomi di wilayah core dan pinggiran periphery. Dengan menggunakan metode Difference-in-Difference, ditemukan bahwa dampak pembangunan Jembatan Suramadu terhadap pertumbuhan ekonomi lebih besar di daerah periphery daripada di daerah core. Hasil ini mungkin juga menimplikasikan bahwa pembangunan Jembatan Suramadu juga mengakibatkan pembentukan gaya sentrifugal
*Korespondensi:

Liza Setya Eka Hasul

E-mail:

amirusolihin@gmail.com 
yang mendorong ekonomi untuk berkembang dari core ke periphery.

Kata Kunci: Core, Jembatan, Periphery, Pertumbuhan

JEL : R1, R4, 04, I1, 12

\section{Pendahuluan}

Jawa timur tercatat sebagai salah satu provinsi dengan kinerja ekonomi terbaik di level nasional. Pertumbuhan ekonomi provinsi Jawa Timur cenderung stabil di level 4-5\% per tahun. Salah satu daerah yang memiliki kontribusi terbesar terhadap perekonomian Jawa Timur adalah Kota Surabaya. Berdasarkan data dari BPS Provinsi Jawa Timur, Kota Surabaya secara konsisten berkontribusi sekitar $24,11 \%$ terhadap laju pertumbuhan ekonomi Jawa Timur sejak tahun 2014 hingga 2018. Daerah-daerah sekitar Kota Surabaya yang juga berkontribusi relatif besar terhadap laju pertumbuhan ekonomi Jawa Timur adalah Kabupaten Sidoarjo dan Gresik yang masing- masing mencatat kontribusi sebesar 8,55\% dan 5,89\% dari tahun 2014 hingga 2018.

Berbeda dengan Kabupaten Sidoarjo dan Gresik, Kabupaten Bangkalan justru menjadi salah satu kabupaten dengan kontribusi terendah meskipun letaknya berdekatan dengan Kota Surabaya. Pada periode 2014 hingga 2018, Kabupaten Bangkalan hanya mencatat kontribusi rata-rata sebesar $1,15 \%$. Hal ini mengindikasikan adanya ketimpangan ekonomi antar daerah yang cukup signifikan di kawasan ini. Perbandingan kontribusi Kabupaten Bangkalan terhadap perekonomian Jawa Timur dengan kota/kabupaten lain yang dekat dengan Kota Surabaya dapat dilihat pada Gambar 1.

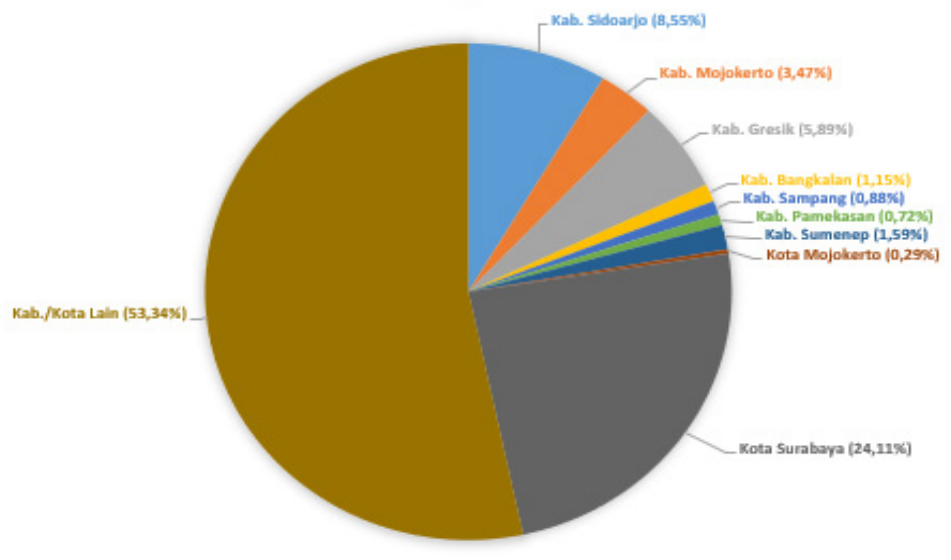

\section{Gambar 1: Rata-Rata Kontribusi Kabupaten/Kota terhadap Produk Domestik Regional Bru- to Provinsi Jawa Timur Periode 2014-2018 \\ Sumber: Badan Pusat Statistik (2019), diolah}

Sebagai salah satu upaya untuk mengurangi ketimpangan antar daerah, pemerintah telah membangun Jembatan Suramadu yang menghubungkan Pulau Jawa melalui Kota Surabaya dengan Pulau Madura melalui Kabupaten Bangkalan. Jembatan Suramadu dibangun pada 20 Agustus 2003 dan diresmikan pada 10 Juni 2009. Dengan dibangunnya jembatan ini, akses ke Pulau Madura dari Pulau Jawa menjadi semakin mudah dan cepat karena pelintas tidak lagi harus menyeberang menggunakan kapal feri. Hal ini tentu saja akan mempermudah sistem logistik menuju Pulau Madura dan meningkatkan daya tarik kabupaten-kabupaten yang ada di Pulau Madura bagi investor. Dalam jangka menengah hingga panjang, pertumbuhan ekonomi di kabupaten-kabupaten di Pulau Madura diprediksi akan mengalami kenaikan 
sebagai dampak positif dari pembangunan jembatan ini sehingga dapat mengurangi ketimpangan antar daerah di Provinsi Jawa Timur.

Untuk mengetahui dampak dari pembangunan Jembatan Suramadu, masih diperlukan studi yang lebih komprehensif. Di satu sisi, masyarakat dan sektor swasta merasakan manfaat langsung berupa kemudahan dalam mobilitas dari dan menuju Pulau Madura. Hal ini seharusnya dapat memicu pertumbuhan industri maupun fasilitas publik baru karena migrasi penduduk yang diakibatkan dari kemudahan akses tersebut merupakan peluang untuk ekspansi pasar. Namun faktanya, dampak terhadap perekonomian kabupaten-kabupaten di Pulau Madura masih belum terlihat secara signifikan hingga beberapa tahun setelah pengoperasian Jembatan Suramadu. Hal ini diindikasikan dengan kontribusi kabupaten-kabupaten di Pulau Madura terhadap PDRB Provinsi Jawa Timur di tahun 2014-2016 yang masih sangatrendah dibandingkan dengan Kota Surabaya dan sekitarnya.

Dengan mempertimbangkan kedekatan lokasinya dengan Kota Surabaya dan sekitarnya yang dapat dikatakan sebagai core dari Provinsi Jawa Timur, Kabupaten Bangkalan dan sekitarnya dapat disebut sebagai daerah periphery. Berdasarkan teori kutub pertumbuhan Perroux, ada dua efek yang dapat timbul dari pembentukan daerah core dengan periphery, yaitu efek sentrifugal dan sentripetal. Apabila efek sentrifugal lebih dominan dalam kasus ini, artinya pembangunan Jembatan Suramadu sudah sesuai dengan tujuannya, yaitu memperlebar pertumbuhan ekonomi menuju daerah periphery seperti Kabupaten Bangkalan. Namun apabila efek sentripetal lebih dominan, maka artinya pembangunan Jembatan Suramadu justru menarik lebih banyak sumber daya alam maupun manusia menuju Kota Surabaya dan akibatnya ketimpangan ekonomi antar daerah akan semakin besar.

Berdasarkan uraian di atas, maka penelitian ini bertujuan untuk mengestimasi dampak pembangunan Jembatan Suramadu terhadap perekonomian daerah-daerah yang berdekatan dengan jembatan tersebut atau yang dinamakan sebagai daerah terdampak. Kemudian penelitian ini juga akan mengestimasi dampak pada daerah core dan periphery untuk melihat gaya yang lebih dominan bekerja sebagai akibat dari konektivitas kedua daerah tersebut. Selain pertumbuhan ekonomi, penelitian ini juga akan melihat dampak terhadap pembangunan di level yang lebih mikro, yaitu di tingkat desa. Pada level desa, estimasi dampak akan dilakukan terhadap beberapa variabel outcome di tiga sektor, yaitu pendidikan, kesehatan dan ekonomi. Hal ini dilakukan untukmelihat lebih dalam dampak dari pembangunan Jembatan Suramadu yang kemungkinan tidak dapat direfleksikan dalam pertumbuhan ekonomi di tingkat kabupaten.

\section{Tinjauan Pustaka}

\section{Teori Pertumbuhan Ekonomi Neoklasik}

Teori ini dikembangkan oleh Solow (1956) dan Swan (1956). Teori ini menggunakan model fungsi produksi yang memungkinkan adanya substitusi antara kapital (K) dan tenaga kerja (L). Pengukuran dari teori ini berdasarkan pada akumulasi modal, pertambahan penawaran tenaga kerja, dan kemajuan teknologi. Dalam hal ini, perubahan teknologi memiliki hubungan yang linierdengan tenaga kerja. Perubahan teknologi yang meningkatkan tenaga kerja menyiratkan bahwa hal tersebut akan meningkatkan produktivitas tenaga kerja.

$$
Y=A f(K, L)
$$

Y merupakan Produk Domestik Bruto (PDB), K merupakan persediaan modal, L merupakan jumlah tenaga kerja dan A merupakan tingkat teknologi yang ditentukan secara ek- 
sogen.

\section{Teori Kutub Pertumbuhan}

Teori kutub pertumbuhan dikemukakan oleh ekonom Perancis, Francois Perroux pada tahun 1950-an. Konsep ruang yang dikemukakan dalam teori ini bukan merupakan ruang geografi, melainkan ruang asbtrak yang disebut sebagai economic space atau ruang ekonomi. Dalam studinya, Perroux (1950) membagi ruang tersebut menjadi tiga: (1) ruang ekonomi berdasarkan perencanaan; (2) ruang ekonomi sebagai medan gaya; dan (3) ruang ekonomi sebagaiagregasi homogen. Definisi ruang ekonomi yang akan dibahas di bagian ini hanya berfokus pada definisi ruang ekonomi sebagai medan gaya.

Menurut teori ini, ruang ekonomi sebagai medan gaya terdiri dari pusat-pusat atau kutub- kutub tempat memancarnya gaya sentrifugal dan tertariknya gaya sentripetal (Perroux, 1950). Perusahaan sebagai pusat medan gaya akan menarik gaya sentripetal yang dapat berupa tenaga kerja atau sumber daya alam ke wilayah produksinya dan mengeluarkan gaya sentrifugal seperti perluasan lahan ke wilayah sekitarnya dan lain-lain. Dalam kasus penelitian ini, Kota Surabaya dapat diibaratkan sebagai suatu ruang ekonomi yang terdiri dari banyak perusahaan sebagai kutub atau pusat pertumbuhannya. Gaya sentripetal yang diakibatkan dari aktivitas ekonomi di Kota Surabaya dapat menarik tenaga kerja dari daerah sekitarnya. Sebaliknya, gaya sentrifugal yang diakibatkan dari aktivitas ekonomi ini dapat membuat permintaan akan tanah di daerah sekitarnya naik karena adanya perluasan usaha.

\section{Teori New Economic Growth}

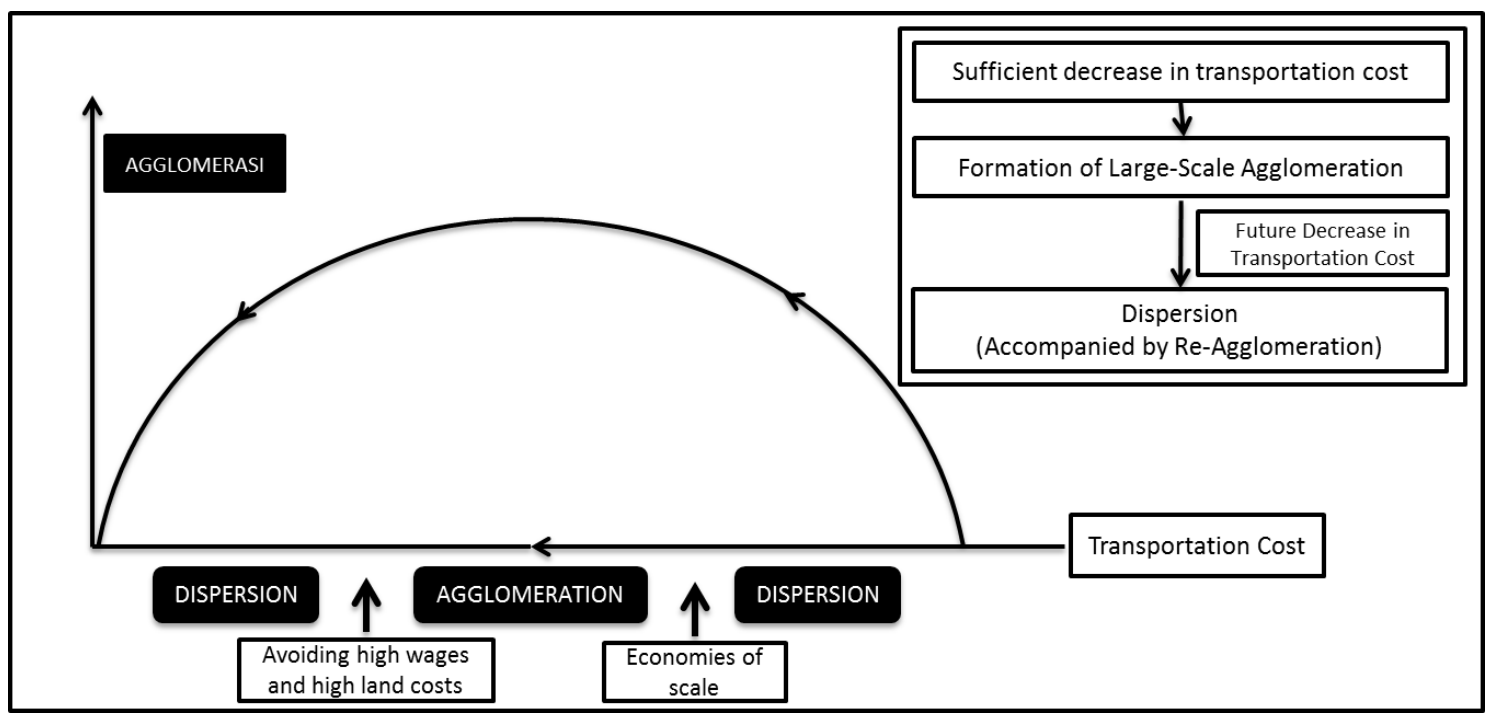

Gambar 2: Aglomerasi dan Dispersi Akibat Penurunan Biaya Transportasi

Sumber: Masahisa (2011)

Teori ini dikemukakan oleh Paul Krugman bahwa sebuah wilayah dapat terbagi menjadi kota inti berteknologi tinggi dan lingkungan sekitarnya yang kurang berkembang. Menurut teori ini, apabila biaya transportasi tinggi, perdagangan antar daerah yang relatif sedikit, sehingga upah pekerjanya tergantung pada jumlah persaingan lokal, dan dengan demikian jumlah pekerja lain di wilayah yang sama menurun. Di sisi lain, ketika biaya transportasi rendah, perusahaan menjual secara luas di kedua wilayah, karena itu akses yang lebih baik ke pasar dari wilayah tersebut dengan populasi yang lebih besar, upah riil pekerja juga lebih tinggi karena pekerja memiliki akses yang lebih baik untuk barang-barang konsumsi (Krugman, 1998, p. 12). 
Jadi dalam hal ini upah riil meningkat dalam populasi suatu wilayah.

Dalam penelitian kali ini, Jembatan Suramadu dapat dijadikan suatu penghubung antara kedua wilayah yang menyebabkan menurunnya biaya transportasi antara Kabupaten Bangkalan dan sekitarnya menuju Surabaya dan sekitarnya maupun sebaliknya. Penurunan biaya transportasi ini memiliki efek yang berbeda tergantung pada tingkat harga. Pada awalnya, penurunan biaya transportasi akan mendorong terciptanya aglomerasi pada salah satu wilayah. Hal ini terjadi saat produsen memusatkan kegiatan produksi pada wilayah yang memiliki tingkat permintaan tinggi. Pada tingkat biaya transportasi tertentu, aglomerasi akan berada pada titik maksimum. Hal ini ditandai dengan tingginya biaya faktor produksi berupa peningkatan biaya sewa lahan dan peningkatan upah tenaga kerja. Maka dari itu, apabila biaya transportasi terus menerus mengalamipenurunan, akan menyebabkan terjadinya dispersi melalui pembubaran aglomerasi lama dan pembentukan aglomerasi aglomerasi baru. Gambar 2 menunjukkan kurva hubungan antara biaya transportasi dengan aglomerasi.

\section{Penelitian Terdahulu}

Penelitian terdahulu banyak membahas mengenai dampak pembangunan infrastruktur terhadap pertumbuhan ekonomi. Banerjee, Duflo \& Qian (2012) menemukan bahwa daerah yang berlokasi dekat dengan jaringan transportasi memiliki nilai Produk Domestik Bruto (PDB), yang lebih tinggi. Hasil ini juga didukung oleh studi dari Preston \& Wall (2008) yang menemukan bahwa dampak dari pembangunan jaringan kereta api berkecepatan tinggi di negara Inggris bagian tenggara berdampak positif walaupun relatif moderat terhadap pertumbuhan ekonomi. Pertumbuhan ekonomi di daerah paling terdampak mengalami kenaikan hingga sekitar $3 \%$.

Pembangunan infrastruktur transportasi yang dapat mendukung interkonektivitas antar daerah seperti jembatan juga dapat berdampak pada aspek sosio-ekonomi masyarakat sekitar. Mahmud dan Sawada (2018) juga menemukan bahwa pembangunan Jembatan Jamuna di Bangladesh berdampak pada pengurangan angka pengangguran dan mendorong pergeseran lapangan pekerjaan masyarakat dari sektor pertanian ke sektor non-pertanian. Jembatan Jamuna merupakan infrastruktur fisik terbesar di Bangladesh yang dibangun tahun 1998 untuk menghubungkan bagian timur dan barat negara tersebut. Selain berdampak dari sisi ekonomi masyararakat, penelitian Mahmud \& Sawada (2018) juga menemukan bahwa pembangunan Jembatan Jamuna mendorong peningkatan angka partisipasi sekolah. Pembangunan infrastruktur transportasi publik juga dapat berdampak pada aspek kesehatan. Hidalgo et al. (2013) menemukan bahwa pembangunan dan pengoperasian sistem Bus Rapid Transit (BRT) di Kota Bogota, Kolombia juga berdampak pada aspek kesehatan dengan mengurangi angka fatalitas dan cedera akibat kecelakaan di jalan melalui perbaikan keamanan transportasi jalan.

Penelitian mengenai dampak infrastruktur interkonektivitas terhadap daerah core dan periphery menunjukkan hasil yang berbeda. Jensen-Butler dan Medsen (1996) menemukan bahwa pembangunan jembatan dan jaringan Great Belt di Denmark lebih menguntungkan untuk daerah core dibanding periphery. Pembangunan jaringan tersebut membuat dua daerah coreutama di Denmark lebih mudah dalam melakukan perdagangan. Sementara itu, daerah periphery yang berada di sebelah utara negara ini akan lebih terisolasi.

Berbeda dengan penelitian di atas, Donaldson (2010) menemukan bahwa infrastruktur transportasi dapat meningkatkan kesejahteraan secara signifikan pada daerah periphery karena memberikan kesempatan pada wilayah tersebut untuk memperoleh keuntungan dari aktivitas perdagangan. Kozlowski (2012) juga menemukan bahwa modernisasi jalan dapat meningkatkan pembangunan bisnis dalam jumlah yang banyak sebagai akibat dari peningka- 
tan akses transportasi penghubung daerah pinggiran menuju ke kota. Hasil studi Meijers et al. (2012) terhadap dampak pembangunan tunnel di bawah bendungan estuari Westerschelde di Belanda juga menunjukkan bahwa interkonektivitas antara core dan periphery lebih menguntungkan daerah periphery. Studi ini menemukan bahwa terjadi penurunan lapangan pekerjaan di daerah core dan sebaliknya, peningkatan lapangan pekerjaan di daerah periphery.

Penelitian mengenai evaluasi dampak pembangunan infrastruktur secara ex-post telah banyak digunakan. Dalam penelitiannya tentang evaluasi dampak pembangunan Jembatan Oresund yang menghubungkan Denmark dengan Swedia, Knudsen \& Rich (2013) menjelaskan bahwa salah satu keunggulan dari metode evaluasi ini adalah dapat mempelajari elemen-elemen yang tidak dapat diprediksi jika melakukan evaluasi secara ex-ante. Dalam studinya, Knudsen \& Rich (2013) menggunakan data dengan rentang waktu 10 tahun dari pengoperasian Jembatan Oresund yang mulai dibuka pada tahun 2000. Evaluasi secara ex-post juga dilakukan oleh Meijers, et al. (2012) untuk mengestimasi dampak pembangunan tunnel bawah dam estuari Westerschelde di Belanda.

\section{Metodologi Penelitian}

\section{Data}

Data yang digunakan untuk estimasi dampak terhadap pertumbuhan ekonomi di tingkat kabupaten adalah data dari Indodapoer. Data ini berasal dari database milik World Bank. Indodapoer terdiri dari 200 indikator yang dikelompokkan menjadi 4, yaitu kelompok indikator fiskal, ekonomi, sosial dan demografi, dan infrastruktur. Data yang tersedia merupakan data tingkat kabupaten dan provinsi. Rata-rata data yang ada di Indodapoer memiliki rentang waktu sejak tahun 2001 hingga tahun terkini dengan keterlambatan sekitar 2 hingga 3 tahun dari tahun berjalan. Data di Indodapoer rata-rata dikumpulkan dari data Badan Pusat Statistik (BPS).

Data yang dipergunakan untuk analisis dampak per sektor di level desa merupakan data Potensi Desa (Podes) dari BPS. Data Podes merupakan sumber data kewilayahan yang memberikan gambaran situasi pembangunan suatu wilayah. Pengumpulan data dilakukan melalui wawancara secara langsung oleh petugas maupun mitra BPS kabupaten atau kota mulai pada tahun 1980. Narasumbernya adalah pihak-pihak yang memiliki pengetahuan terhadap daerah target pencacahan. Ketersediaan data Podes yang mendekati tahun penelitian adalah pada tahun 2003, 2008, 2011, 2014.

Dari segi periode, data yang dipilih adalah data Podes tahun 2003 dan 2014. Hal ini sejalan dengan tujuan penulis untuk menganalisis dampak pembangunan Jembatan Suramadu yang proses pembangunannya dimulai pada bulan Agustus 2003. Pemilihan data tahun 2014 didasarkan pada argumen penulis bahwa dampak dari pembangunan suatu infrastruktur seperti jembatan dapat dilihat dari jangka waktu menengah hingga panjang. Data tahun 2011 terlalu dekat dengan tahun operasi, yaitu tahun 2009, sehingga kemungkinan tidak mampu menangkap dampak yang sebenarnya dari pembangunan Jembatan Suramadu. Dari segi wilayah, data yang digunakan hanya berfokus pada Provinsi Jawa Timur dengan jumlah observasi sebanyak 16.967 desa.

\section{Model dan Metode Estimasi}

Salah satu metode estimasi data panel adalah menggunakan Fixed-Effect (FE). Ada dua jenis metode FE yaitu Least Square Dummy Variable (LSDV) dan Within Group (WG). Penelitian ini menggunakan FE berjenis WG untuk mengestimasi data. Berbeda dengan FE WG, model FE LSDV membutuhkan variabel dummy per unit cross section dan atau time series. Metode 
tersebut tidak efisien jika diterapkan pada penelitian ini karena unit cross section yang ada sangat banyak untuk estimasi model di level desa. Selain itu, kerugian lain dari penggunaan FE LSDV adalah model yang digunakan akan menghabiskan degree of freedom karena banyaknya variabel dummy yang dimasukkan (Gujarati \& Porter, 2012: 262).

Koefisien pada Fixed-Effect Model (FEM) diperoleh dari hasil selisih antara nilai individu dengan rata-rata nilai individu sepanjang waktu. Apabila variabel bersifat time-invariant atau konstan antar waktu, maka koefisien akan menjadi nol dan variabel tersebut dikeluarkan dari model. Hal ini dapat menjadi kelemahan sekaligus kelebihan dari FEM. Penggunaan FEM berarti dapat menghilangkan error term yang sifatnya konstan antar waktu dan hal ini merupakan salah satu alasan penggunaan FEM. Namun hal tersebut juga berarti pemilihan variabel dalam model perlu memperhatikan perubahannya antar waktu karena variabel yang konstan antar waktu akan dikeluarkan dari model. Kelemahan ini menjadi salah satu kendala yang dihadapi saat membangun model dalam penelitian ini. Variabel independen utama di model-model yang digunakan, yaitu dummy daerah treated (TR), dummy daerah core (CORE) dan dummy daerah periphery (PERI), merupakan variabel yang konstan antar waktu sehingga koefisien variabel tersebut tidak dapat diestimasi.

Untuk mengatasi masalah tersebut, penelitian ini menggunakan metode estimasi dampak Difference-in-Difference (DID). Pada metode ini, dampak diperoleh dari selisih antara outcome kelompok treated dan control pada sebelum dan sesudah waktu intervensi. Oleh karena itu, dibutuhkan interaksi antara dummy kelompok treated (TR) dan tahun intervensi (TI) yang diperlakukan sebagai suatu variabel tersendiri dan memiliki koefisien. Koefisien dari interaksi kedua variabel tersebut dinamakan estimator DID. Dengan adanya interaksi tersebut, analisis tetap dapat menggunakan variabel yang konstan antar waktu seperti TR, CORE dan PERI. Berdasarkan penjelasan di atas, model yang diestimasi adalah sebagai berikut.

\section{Model Untuk Estimasi Tingkat Kabupaten:}

$$
\begin{aligned}
\ln P D R B_{i t}= & \beta_{0}+\beta_{1} T 1 * T R_{i t}+\beta_{2} \ln P O P_{i t}+\beta_{3} S D_{i t}+\beta_{4} S M P_{i t}+ \\
& \beta_{5} S M A_{i t}+\beta_{6} D O C_{i t}+\beta_{7} L R_{i t}+\beta_{8} \ln C A P_{i t}+c_{i t} \\
\ln P D R B_{i t}= & \beta_{0}+\beta_{1} T 1 * C O R E_{i t}+\beta_{2} \ln P O P_{i t}+\beta_{3} S D_{i t}+\beta_{4} S M P_{i t}+ \\
& \beta_{5} S M A_{i t}+\beta_{6} D O C_{i t}+\beta_{7} L R_{i t}+\beta_{8} \ln C A P_{i t}+s_{i t} \\
\ln P D R B_{i t}= & \beta_{0}+\beta_{1} T 1 * P E R I_{i t}+\beta_{2} \ln P O P_{i t}+\beta_{3} S D_{i t}+\beta_{4} S M P_{i t}+ \\
& \beta_{5} S M A_{i t}+\beta_{6} D O C_{i t}+\beta_{7} L R_{i t}+\beta_{8} \ln C A P_{i t}+\mu_{i t}
\end{aligned}
$$

Model Untuk Estimasi Tingkat Desa:

$$
\begin{gathered}
Y_{i t}=\beta_{0}+\beta_{1} T 1 * T R_{i t}+\beta_{2} \ln P_{i t}+\sigma_{i t} \\
Y_{i t}=\beta_{0}+\beta_{1} T 1 * C O R E_{i t}+\beta_{2} \ln P_{i t}+\theta_{i t} \\
Y_{i t}=\beta_{0}+\beta_{1} T 1 * P E R I_{i t}+\beta_{2} \ln P_{i t}+P_{i t}
\end{gathered}
$$

Model (1), (2) dan (3) digunakan untuk mengetahui dampak pembangunan Jembatan Suramadu terhadap pertumbuhan ekonomi di daerah terdampak (TR), core (CORE) dan periphery (PERI) di tingkat kabupaten. Definisi TR, CORE dan PERI dapat dilihat pada tabel 3.1. 
Data yangdigunakan untuk estimasi model (1), (2) dan (3) adalah data makro tingkat kabupaten yang didapatkan dari dataset Indodapoer. Variabel yang digunakan sebagai proxy dari pertumbuhan ekonomi adalah logaritma natural dari Produk Domestik Reginal Bruto (PDRB). Variabel kontrol yang digunakan didasarkan pada model pertumbuhan ekonomi neoklasik. Angka literasi (LR) dan populasi (POP) menjadi proxy dari kualitas dan kuantitas labor yang merupakan salah satu input dari pertumbuhan ekonomi di model neoklasik. Sementara itu, jumlah SD (SD), jumlah SMP (SMP), jumlah SMA (SMA) dan jumlah dokter (DOC) merupakan proxy dari jumlah capital. CAP adalah pengeluaran pemerintah untuk modal. Variabel ini juga dimasukkan sebagai variabel kontrol dengan pertimbangan bahwa kuantitas modal di suatu daerah dipengaruhi oleh belanja modal dari pemerintah. TI adalah dummy untuk tahun intervensi yang bernilai 1 untuk tahun 2009 dan sesudahnya. Tahun 2009 dipilih sebagai tahun intervensi karena di tahun ini Jembatan Suramadu mulai beroperasi.

Tabel 1: Definisi Variabel TR, CORE dan PERI

\begin{tabular}{|c|c|c|}
\hline Data & Nama Variabel & Keterangan \\
\hline \multirow[t]{7}{*}{ Indodapoer } & Treatment 1 (TR1) & $\begin{array}{l}\text { Bernilai } 1 \text { untuk Kota Surabaya dan Kabupat- } \\
\text { en Bangkalan; } 0 \text { untuk kabupaten lain di Provinsi Jawa } \\
\text { Timur. }\end{array}$ \\
\hline & Treatment 2 (TR2) & $\begin{array}{l}\text { Bernilai } 1 \text { untuk Kota Surabaya, Kabupaten Bangkalan } \\
\text { dan Kabupaten Sampang; } 0 \text { untuk kabupaten lain di } \\
\text { Provinsi Jawa Timur. }\end{array}$ \\
\hline & Treatment 3 (TR3) & $\begin{array}{l}\text { Bernilai } 1 \text { untuk Kota Surabaya, Kabupaten Bangka- } \\
\text { lan Kabupaten Sampang dan Kabupaten Pamekasan; } 0 \\
\text { untukkabupaten lain di Provinsi Jawa Timur. }\end{array}$ \\
\hline & Treatment 4 (TR4) & $\begin{array}{l}\text { Bernilai } 1 \text { untuk Kota Surabaya, Kabupaten Bangkalan } \\
\text { Kabupaten Sampang Kabupaten Pamekasan } \\
\text { dan Kabupaten Sumenep; } 0 \text { untuk kabupaten lain di } \\
\text { ProvinsiJawa Timur. }\end{array}$ \\
\hline & Treatment 5 (TR5) & $\begin{array}{l}\text { Bernilai } 1 \text { untuk Kota Surabaya, Kabupaten Bangkalan } \\
\text { Kabupaten Sampang Kabupaten Pamekasan, Kabupaten } \\
\text { Sumenep, Kabupaten Gresik, Kabupaten Sidoarjo, Kota } \\
\text { Mojokerto dan Kabupaten Mojokerto; } 0 \text { untuk kabupat- } \\
\text { en lain di Provinsi Jawa Timur. }\end{array}$ \\
\hline & CORE & $\begin{array}{l}\text { Bernilai } 1 \text { untuk Kota Surabaya, Kabupaten Gresik, Kabu- } \\
\text { paten Sidoarjo, Kota Mojokerto dan Kabupaten Mojok- } \\
\text { erto; } 0 \text { untuk Kabupaten Bangkalan Kabupaten Sampang } \\
\text { Kabupaten Pamekasan dan Kabupaten Sumenep. }\end{array}$ \\
\hline & PERI & $\begin{array}{l}\text { Bernilai } 1 \text { untuk Kabupaten Bangkalan Kabupaten Sam- } \\
\text { pang Kabupaten Pamekasan dan Kabupaten Sumenep; } \\
0 \text { untuk Kota Surabaya, Kabupaten Gresik, Kabupaten } \\
\text { Sidoarjo, Kota Mojokerto dan Kabupaten Mojokerto. }\end{array}$ \\
\hline
\end{tabular}


Bernilai 1 untuk Kelurahan atau Desa yang berbatasan langsung dengan Jembatan Suramadu (Kelurahan Sukolilo Barat dan Desa Tambak Wedi); 0 untuk desalain yang berada pada Kecamatan Labang dan Kenjeran.

Treatment 2 (TR2) Bernilai 1 untuk desa di kecamatan yang berbatasan langsung dengan Jembatan Suramadu (Kecamatan Labang pada pulau madura dan Kecamatan Kenjeran pada Surabaya); 0 untuk desa di kecamatan yg berbatasan langsung dengan kecamatan terdampak, antara lain: Tambaksari, Simokerto, Bulak, Semampir di Surabayaserta Kamal, Kwanyar, Tragah, dan Socah di Bangkalan.

\begin{tabular}{ll}
\hline Treatment 3 (TR3) & $\begin{array}{l}\text { Bernilai 1 untuk desa di kecamatan terdampak } \\
\text { dan sekitarnya; 0 untuk desa di kecamatan lain yang } \\
\text { beradapada Kabupaten Bangkalan dan Kota Surabaya. }\end{array}$ \\
\hline Treatment 4 (TR4) & $\begin{array}{l}\text { Bernilai } 1 \text { untuk desa di Kota Surabaya dan Kabupaten } \\
\text { Bangkalan; 0 untuk desa di Kabupaten yang berada pada } \\
\text { sekitar dummy 1 yaitu Kabupaten Sidoarjo, Gresik, } \\
\text { Sampang, Pamekasan, dan Sumenep. }\end{array}$ \\
\hline Treatment 5 (TR5) & $\begin{array}{l}\text { Bernilai 1 untuk desa di Kabupaten Bangkalan, Sam- } \\
\text { pang,dan Kota Surabaya; 0 untuk desa di Kabupaten }\end{array}$ \\
& Sidoarjo, Gresik, Pamekasan dan Sumenep. \\
\hline Treatment 6 (TR6) & $\begin{array}{l}\text { Bernilai 1 untuk desa di Kabupaten Bangkalan, Sam- } \\
\text { pang, Pamekasan dan Kota Surabaya; 0 untuk desa di } \\
\text { Kabupaten Sidoarjo, Gresik, dan Sumenep. }\end{array}$ \\
\hline Treatment 7 (TR7) & $\begin{array}{l}\text { Bernilai } 1 \text { untuk desa di Kabupaten Bangkalan, Sam- } \\
\text { pang, Pamekasan, Sumenep dan Kota Surabaya; 0 untuk } \\
\text { desa diKabupaten Sidoarjo dan Gresik. }\end{array}$ \\
\hline Treatment 8 (TR8) & Bernilai 1 untuk desa di Kabupaten Bangkalan, Sampang, \\
\hline
\end{tabular}

Sumber: Analisis Penulis

Model (4), (5) dan (6) digunakan untuk mengetahui dampak pembangunan Jembatan Suramadu terhadap pembangunan di sektor pendidikan, kesehatan dan ekonomi di daerah terdampak (TR), core (CORE) dan periphery (PERI) pada tingkat desa. Data yang digunakan berasal dari dataset Podes tahun 2003 dan 2014. Y merupakan serangkaian dari variabel outcome dari tiga sektor yaitu pendidikan, kesehatan dan ekonomi. Variabel outcome yang dikategorikan dalam sektor kesehatan dan ekonomi masing-masing berjumlah 10 . Variabel outcome yang dikategorikan dalam sektor pendidikan ada 11, sehingga total ada 31 variabel outcome yang diestimasi. Detail nama variabel outcome yang diestimasi dapat dilihat di tabel 2. TR dalam model (4) memiliki 8 definisi yang dapat dilihat di tabel 1.

Tabel 2: Daftar Indikator Per Sektor

\begin{tabular}{cl} 
Sektor & \multicolumn{1}{c}{ Indikator } \\
\hline Ekonomi & $\begin{array}{c}\text { Jumlah UKM Kerajinan anyaman, gerabah dan keramik, UKM kerajinan } \\
\text { kulit, UKM kerajinan kayu, UKM kerajinan logam, UKM kerajinan kain } \\
\text { tenun, UKM kerajinan makanan, restoran, toko dan hotel. }\end{array}$ \\
\hline $\begin{array}{c}\text { Pendi- } \\
\text { dikan }\end{array}$ & $\begin{array}{l}\text { Jumlah SD negeri, SMP negeri, SMU negeri, SMK negeri, SD swasta, SMP } \\
\text { swasta, SMU swasta, PTN, PTS dan pondok pesantren. }\end{array}$ \\
\hline
\end{tabular}


Sektor

Kesehatan
Indikator

Jumlah rumah sakit umum, rumah sakit bersalin, puskesmas, poliklinik, polindes, praktik dokter, praktik bidan, posyandu, dan apotek.

Sumber: Analisis Penulis

Variabel kontrol untuk model (4), (5) dan (6) hanya ada 1 yaitu logaritma natural dari Pendapatan Asli Desa (InP). Variabel tersebut dimasukkan untuk mengontrol ukuran desa yang dilihat dari pendapatannya. Tidak seperti data Indodapoer, variabel yang ada di data Podes cenderung mengalami modifikasi di setiap gelombang. Di Podes gelombang terbaru (2014), terdapat penghilangan, perubahan, modifikasi dan penambahan variabel baru sehingga agak berbeda dengan Podes tahun 2003. Hal ini membuat beberapa variabel menjadi ambigu karena perubahan yang diterapkan membuat data tahun 2014 tidak dapat dijamin keseragamannya dengan tahun 2003. Oleh karena itu, pemilihan variabel harus dilakukan dengan berhati-hati. Dari seluruh variabel kontrol yang memungkinkan untuk dimasukkan ke model, hanya PAD yang seragam pengertian dan pengukurannya antar gelombang.

\section{Hasil dan Pembahasan}

\section{Dampak Pembangunan Jembatan Suramadu terhadap Pertumbuhan Ekonomi di Wilayah Core dan Periphery}

Sebelum mengestimasi dampak untuk daerah core dan periphery, penelitian ini terlebih dahulu mengestimasi dampak untuk daerah-daerah yang secara langsung berhubungan dengan Jembatan Suramadu. Daerah yang dimaksud meliputi Kota Surabaya, Kabupaten Bangkalan, Kabupaten Sampang, Kabupaten Pamekasan, Kabupaten Sumenep, Kabupaten Gresik dan Kabupaten Sidoarjo. Daerah-daerah tersebut digolongkan menjadi 5 definisi daerah terdampak (TR). Penggolongan didasarkan pada jarak daerah-daerah tersebut dengan Jembatan Suramadu. Detail definisi daerah TR dapat dilihat di Tabel 1.

Hasil estimasi menunjukkan bahwa pembangunan Jembatan Suramadu tidak berdampak pada pertumbuhan ekonomi untuk daerah terdampak. Hal ini diindikasikan oleh estimator DID seluruh TR yang tidak signifikan. Meskipun demikian, seluruh koefisien interaksi TR dengan TI tersebut bernilai positif. Artinya, meskipun tidak signifikan, pembangunan Jembatan Suramadu berdampak positif terhadap pertumbuhan ekonomi. Kelemahan penggunaan variabel TR adalah penggolongannya yang didasarkan pada jarak membuat Kota Surabaya selalu disandingkan bersama Kabupaten Bangkalan sebagai kelompok treated. Padahal kedua daerah tersebut memiliki karakteristik yang berbeda. Surabaya merupakan kota metropolitan dengan PDRB yang cukup tinggi dibandingkan dengan Kabupaten Bangkalan yang merupakan rural area. Oleh karena itu, penelitian ini mengembangkan model (1) dengan mengganti variabel TR dengan variabel dummy yang lebih mampu membedakan dan menggolongkan daerah berdasarkan karakteristiknya.

Model (2) dan (3) merupakan modifikasi dari model (1) yang mengganti variabel TR dengan variabel CORE dan PERI. CORE adalah dummy untuk sekelompok daerah yang digolongkan sebagai wilayah core. Penggolongan ini didasarkan pada karakteristik daerah core yang merupakan pusat aktivitas ekonomi regional yaitu memiliki pendapatan atau output yang relatif lebih tinggi dibandingkan kawasan lain di sekitarnya. Core dalam penelitian ini meliputi Kota Surabaya, Kabupaten Gresik, Kabupaten Sidoarjo, Kota Mojokerto dan Kabupaten Mojokerto. Kelima daerah tersebut memiliki kontribusi yang relatif tinggi terhadap PDRB Provinsi Jawa Timur. Hal ini berarti sebagian besar aktivitas ekonomi di Provinsi Jawa Timur berpusat 
di wilayah ini sehingga dapat dikatakan bahwa wilayah ini merupakan core di Jawa Timur. Wilayah yang didefinisikan sebagai daerah periphery dalam penelitian ini adalah seluruh kabupaten yang berada di Pulau Madura. Wilayah periphery memiliki karakteristik yang berbeda dengan core. Wilayah periphery pada umumnya merupakan wilayah pedesaan. Kontribusi wilayah ini terhadap PDRB Jawa Timur cenderung rendah karena bukan merupakan pusat aktivitas ekonomi. Perbandingan kontribusi core dan periphery terhadap PDRB Provinsi Jawa Timur dapat dilihat pada Gambar 3.

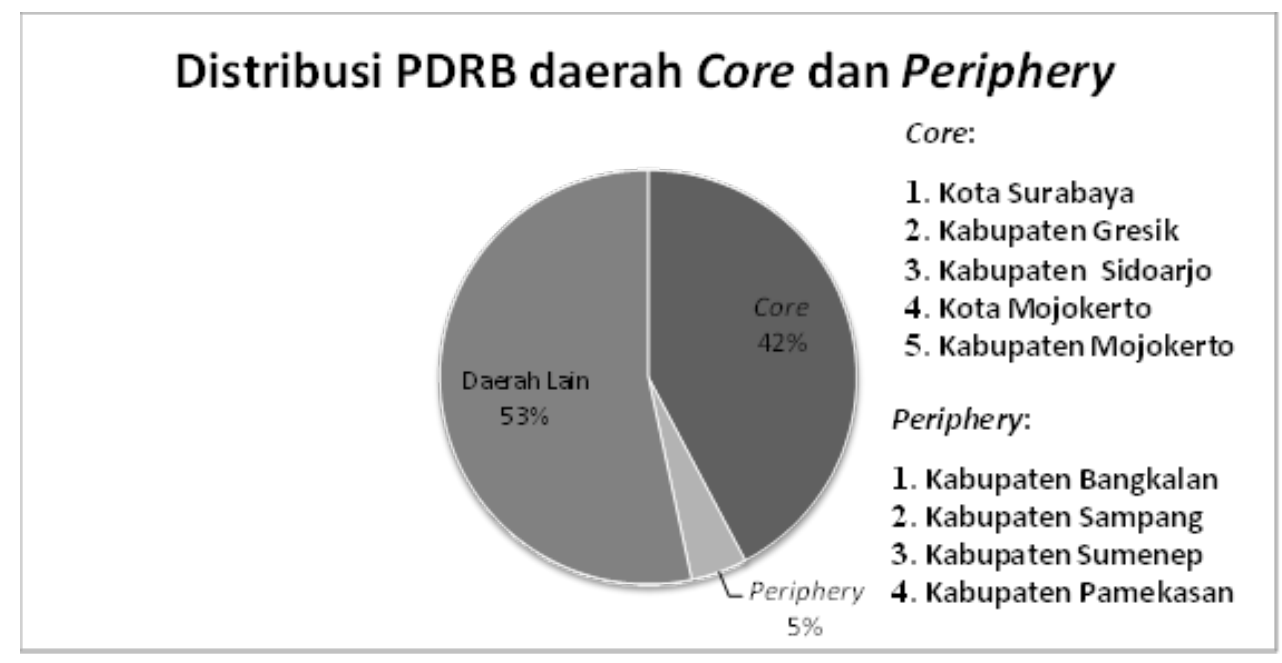

Sumber: BPS, 2018 (diolah)

Estimasi dampak menggunakan variabel CORE dan PERI menghasilkan estimator yang signifikan. Artinya, pembangunan Jembatan Suramadu berdampak signifikan terhadap pertumbuhan ekonomidaerah core dan periphery. Estimator variabel CORE yang negatif menandakan bahwa pertumbuhanekonomi, sebagai dampak dari pembangunan Jembatan Suramadu, untuk daerah core lebih rendah daripada daerah periphery. Hal ini juga dibuktikan dengan nilai estimator PERI yang positif. Kesimpulannya adalah bahwa pembangunan Jembatan Suramadu berdampak pada kenaikan PDRB sebesar 0,0981\% pada kawasan periphery. Hal ini mengindikasikan bahwa gaya yang dominan bekerja sebagai dampak dari pembangunan Jembatan Suramadu ini adalah gaya sentrifugal. Gaya ini mendorong pertumbuhan ekonomi ke luar area core menuju periphery.

\section{Dampak Pembangunan Jembatan Suramadu terhadap Pembangunan di Sektor Pendidikan, Kesehatan dan Ekonomi di Tingkat Desa}

Untuk melihat lebih dalam mengenai dampak pembangunan Jembatan Suramadu, studi ini meneliti dampak pada unit penelitian yang lebih kecil, yaitu desa. Estimasi dampak dilakukan pada 31 variabel outcome tingkat desa yang terbagi ke dalam tiga sektor yaitu pendidikan, kesehatan dan ekonomi. Penelitian ini menggunakan 8 definisi kawasan terdampak untuk estimasidi tingkat desa. Pembangunan Jembatan Suramadu kemungkinan mendorong adanya migrasi penduduk menuju desa-desa di kawasan terdampak sehingga hal ini kemudian mendorong pertumbuhan ekonomi di tingkat desa yang dilihat dari pembangunan jumlah toko, restoran, dan Usaha Kecil dan Menengah (UKM) baru. Selain itu, pertambahan penduduk akibat migrasi ini juga kemungkinan mendorong pembangunan fasilitas pendidikan dan kesehatan baru di kawasan terdampak.

\section{Sektor Pendidikan}


Berdasarkan hasil estimasi, semakin sempit definisi daerah terdampak, maka akan semakin sedikit estimator DID variabel pendidikan yang signifikan. Pada daerah definisi TR1, estimator untuk seluruh indikator pendidikan tidak bernilai signifikan. Hal ini berarti pembangunan Jembatan Suramadu tidak secara khusus meningkatkan jumlah fasilitas pendidikan di dua desa terdampak utama, yaitu Desa Sukolilo Barat di Kabupaten Bangkalan dan Kelurahan Tambak Wedi di Kota Surabaya. Pada daerah definisi TR2, estimator untuk jumlah SMK swasta dan pondok pesantren bernilai signifikan dan positif. Artinya, ada kenaikan jumlah SMK swasta dan pondok pesantren di desa-desa di dua kecamatan terdampak utama yaitu Kecamatan Kenjeran di Surabaya dan Kecamatan Labang di Bangkalan setelah pembangunan Jembatan Suramadu. Kenaikan jumlah SMK swasta dan pondok pesantren tersebut kemungkinan dialami oleh desa selain dua desa terdampak utama, mengingat estimator kedua indikator tersebut tidak signifikan pada TR1. Pada definisi yang lebih luas, yaitu TR3, estimator untuk seluruh indikator pendidikan tidak ada yang bernilai signifikan dan positif.

Tabel 3: Indikator Pendidikan yang Memiliki Estimator DID Positif dan Signifikan

\begin{tabular}{|c|c|c|c|c|c|c|c|c|c|c|c|}
\hline \multirow{2}{*}{$\begin{array}{c}\text { Nama Variabel } \\
\text { Dummy }\end{array}$} & \multicolumn{11}{|c|}{ Indikator Pendidikan } \\
\hline & SDN & SDS & SMPN & SMPS & SMUN & SMUS & SMKN & SMKS & PTN & PTS & Ponpes \\
\hline \multicolumn{12}{|l|}{ TR1 } \\
\hline \multicolumn{12}{|l|}{ TR2 } \\
\hline \multicolumn{12}{|l|}{ TR3 } \\
\hline \multicolumn{12}{|l|}{ TR4 } \\
\hline \multicolumn{12}{|l|}{ TR5 } \\
\hline \multicolumn{12}{|l|}{ TR6 } \\
\hline \multicolumn{12}{|l|}{ TR7 } \\
\hline \multicolumn{12}{|l|}{ TR8 } \\
\hline \multicolumn{12}{|l|}{ Core } \\
\hline Periphery & & & & & & & & & & & \\
\hline
\end{tabular}

Sumber: Hasil Estimasi Penulis

Estimasi pada tingkat kabupaten menghasilkan estimator-estimator yang relatif lebih konsisten signifikansinya meskipun definisi daerah terdampak berubah. Secara umum, indikator yang konsisten di daerah definisi level kabupaten adalah jumlah SD negeri, SD swasta, SMP negeri, SMP swasta, SMU swasta, dan SMK swasta. Estimator untuk jumlah perguruan tinggi swasta (PTS) baru bernilai signifikan dan positif di daerah definisi terluas, yaitu TR8. Artinya, jumlah PTS mengalami kenaikan di kabupaten terdampak dan sekitarnya setelah pembangunan jembatan Suramadu. Estimator yang tidak pernah bernilai signifikan adalah jumlah SMU negeri, SMK negeri dan PTN. Hal ini berarti pembangunan Jembatan Suramadu tidak meningkatkan jumlah SMU negeri, SMK negeri dan PTN di daerah terdampak.

Pada sektor pendidikan, daerah periphery mengalami pertambahan jumlah sekolah swasta baru sebagai dampak dari pembangunan jembatan suramadu. Hal ini diindikasikan dengan nilai estimator jumlah SD swasta, SMP swasta, SMU swasta dan SMK swasta yang positif dan signifikan untuk estimasi model daerah periphery. Sementara itu di bagian core, estimator indikator pendidikan yang bernilai signifikan dan positif adalah jumlah pondok pesantren. 
Sekolah swasta memiliki estimator yang cenderung signifikan dan positif dibanding sekolahnegeri. Hal ini mengindikasikan bahwa pembangunan jembatan Suramadu mendorong pertumbuhan sekolah-sekolah swasta baru di berbagai jenjang pendidikan. Tidak seperti sekolah negeri, pendirian sekolah swasta memang cenderung lebih mudah. Faktor-faktor yang mempengaruhi keputusan suatu entitas untuk membangun sekolah swasta adalah ketersediaan akses, sarana dan siswa. Pembangunan jembatan Suramadu secara tidak langsung meningkatkan akses ke daerah-daerah baru melalui pembangunan jalan-jalan penghubung. Ketika akses ke daerah-daerah tersebut telah terbuka, maka sarana pendukung seperti listrik maupun air akan semakin memadai. Hal ini kemudian akan menarik penduduk baru sehingga permintaan akan pendidikan juga akan bertambah.

\section{Sektor Kesehatan}

Pada daerah definisi TR1, indikator kesehatan yang bernilai signifikan dan positif adalah jumlah praktik bidan. Estimator jumlah praktik bidan merupakan estimator yang paling konsisten bernilai signifikan dan positif dalam sektor kesehatan. Di antara delapan daerah definisi yang ada, hanya di TR3 saja estimator jumlah praktik bidan tidak bernilai signifikan. Meskipun demikian, estimator ini bernilai negatif di TR2. Artinya, jumlah praktik bidan di desa-desa di kecamatan terdampak lebih rendah daripada di desa-desa di kecamatan sekitarnya. Meskipun jumlah praktik bidan di Desa Sukolilo Barat dan Kelurahan Tambak Wedi lebih banyak dibandingkan dengan desa lain di kecamatan yang sama, namun kemungkinan jumlah praktik bidan di kecamatan sekitar Labang dan Kenjeran tumbuh lebih cepat sehingga nilai estimator variabel ini di TR2 negatif. Jika dibandingkan dengan desa di kecamatan lain di kabupaten yang sama, pertumbuhan jumlah praktik bidan di kecamatan Labang dan Kenjeran tidak menunjukkan adanya perbedaan. Hal ini diindikasikan dengan estimator yang positif namun bernilai sangat kecil dan tidak signifikan.

Tabel 4: Indikator Kesehatan yang Memiliki Estimator DID Positif dan Signifikan

\begin{tabular}{|c|c|c|c|c|c|c|c|c|c|c|}
\hline \multirow{2}{*}{$\begin{array}{l}\text { Nama } \\
\text { Variabel } \\
\text { Dummy }\end{array}$} & \multicolumn{10}{|c|}{ Indikator Kesehatan } \\
\hline & RS & $\begin{array}{l}\text { RS Ber- } \\
\text { salin }\end{array}$ & $\begin{array}{c}\text { Puskes- } \\
\text { mas }\end{array}$ & $\begin{array}{c}\text { Pus- } \\
\text { tu }\end{array}$ & Polindes & Poliklinik & Posyandu & $\begin{array}{c}\text { Praktek } \\
\text { Dokter }\end{array}$ & $\begin{array}{c}\text { Praktek } \\
\text { Bidan }\end{array}$ & Apotek \\
\hline TR1 & & & & & & & & & & \\
\hline TR2 & & & & & & & & & & \\
\hline TR3 & & & & & & & & & & \\
\hline TR4 & & & & & & & & & & \\
\hline TR5 & & & & & & & & & & \\
\hline TR6 & & & & & & & & & & \\
\hline TR7 & & & & & & & & & & \\
\hline TR8 & & & & & & & & & & \\
\hline Core & & & & & & & & & & \\
\hline Periphery & & & & & & & & & & \\
\hline
\end{tabular}

Sumber: Hasil Estimasi Penulis

Selain jumlah praktik bidan, estimator yang signifikan tapi bernilai negatif di TR2 adalah estimator jumlah pondok bersalin desa (polindes). Pada TR3, estimator polindes bernilai positif namun tidak signifikan. Kemudian di tingkat kabupaten (TR4-TR8), estimator polindes konsisten bernilai positif dan signifikan. Pola ini hampir sama dengan estimator praktik bidan. 
Hal ini mengindikasikan adanya korelasi antara jumlah bidan di desa dengan jumlah polindes. Dengan adanya pertumbuhan jumlah polindes berarti ada lebih banyak bidan yang bekerja di desa tersebut. Kemungkinan bidan-bidan ini membuka praktik sendiri sebagai pekerjaan sampingan selain bekerja di polindes.

Dua estimator lain yang cenderung signifikan di TR4-TR8 adalah estimator jumlah puskesmas dan posyandu. Kenaikan jumlah puskesmas dan posyandu kemungkinan banyak terjadi di Pulau Madura bagian timur. Hal ini diindikasikan dengan mulai signifikannya estimator kedua variabel tersebut ketika daerah definisi diperluas dengan menambahkan kabupaten- kabupaten di bagian timur Pulau Madura. Kenaikan jumlah posyandu diindikasi memiliki korelasidengan kenaikan fasilitas bersalin seperti polindes dan praktik bidan. Di desa, posyandu berfungsi untuk pelayanan cek kesehatan balita dan ibu hamil. Pertumbuhan jumlah praktik bidan, polindes dan posyandu terutama di bagian timur Pulau Madura setelah adanya Jembatan Suramadu mengindikasikan adanya migrasi penduduk ke daerah ini. Migrasi tersebut kemungkinan dilakukan oleh penduduk yang sudah berkeluarga seperti yang diindikasikan dengan kebutuhan akan fasilitas bersalin yang meningkat di daerah ini.

Pada sektor kesehatan, indikator yang bernilai positif dan signifikan di periphery adalah jumlah puskesmas, polindes, posyandu dan praktik bidan. Sementara itu untuk model yang menggunakan core, tidak ada estimator indikator kesehatan yang bernilai signifikan. Artinya, pembangunan Jembatan Suramadu tidak berdampak pada jumlah fasilitas kesehatan di daerah core.

\section{Sektor Ekonomi}

Variabel di sektor ekonomi dengan estimator yang paling konsisten bernilai signifikan dan positif adalah jumlah restoran. Meskipun demikian, estimator ini hanya konstan pada estimasi tingkat kabupaten (TR4-TR8). Artinya, tidak ada pertumbuhan jumlah restoran yang signifikan di desa-desa pada kecamatan terdampak dan sekitarnya. Restoran-restoran baru kemungkinan berada di luar kecamatan terdampak. Hal ini diindikasikan dengan estimator variabel ini yang bernilai signifikan dan negatif di TR3.

Tabel 5: Indikator Ekonomi yang Memiliki Estimator DID Positif dan Signifikan

\begin{tabular}{|c|c|c|c|c|c|c|c|c|c|c|}
\hline \multirow[b]{2}{*}{$\begin{array}{c}\text { Nama } \\
\text { Variabel } \\
\text { Dummy }\end{array}$} & \multicolumn{10}{|c|}{ Indikator Ekonomi } \\
\hline & Toko & $\begin{array}{l}\text { Mini- } \\
\text { market }\end{array}$ & Restoran & $\begin{array}{l}\text { Ho- } \\
\text { tel }\end{array}$ & $\begin{array}{c}\text { UKM } \\
\text { Makanan }\end{array}$ & $\begin{array}{l}\text { UKM } \\
\text { Kulit }\end{array}$ & $\begin{array}{l}\text { UKM } \\
\text { Logam }\end{array}$ & $\begin{array}{l}\text { UKM Kain } \\
\text { Tenun }\end{array}$ & $\begin{array}{l}\text { UKM- } \\
\text { Kayu }\end{array}$ & $\begin{array}{c}\text { UKM } \\
\text { Anyaman, } \\
\text { Gerabah } \\
\text { Keramik }\end{array}$ \\
\hline TR1 & & & & & & & & & & \\
\hline TR2 & & & & & & & & & & \\
\hline TR3 & & & & & & & & & & \\
\hline TR4 & & & & & & & & & & \\
\hline TR5 & & & & & & & & & & \\
\hline TR6 & & & & & & & & & & \\
\hline TR7 & & & & & & & & & & \\
\hline TR8 & & & & & & & & & & \\
\hline Core & & & & & & & & & & \\
\hline Periphery & & & & & & & & & & \\
\hline
\end{tabular}

Sumber: Hasil Estimasi Penulis 
Variabel jumlah toko merupakan variabel selain jumlah restoran yang cenderung benilai signifikan dan positif. Estimator variabel ini cukup besar di TR1 dan TR2. Hal ini mengindikasikan pesatnya pembangunan toko-toko baru di kecamatan terdampak, terutama di dua desa utama, Sukolilo Barat dan Tambak Wedi. Meskipun demikian, estimator variabel ini tidak signifikan di TR3 dan TR4. Artinya, pertumbuhan toko-toko baru hanya terpusat di desa-desa di kecamatan terdampak saja. Toko-toko tersebut kemungkinan berada di kaki jembatan Suramadu, yaitu di sepanjang Jalan H. Moh. Noer di sisi Madura dan Jalan Kedung Cowek di sisi Surabaya.

Berbeda dengan toko, jumlah minimarket justru cenderung memiliki estimator yang negatif. Estimator yang negatif di TR4 hingga TR7 menandakan bahwa pertumbuhan jumlah minimarket di Pulau Madura lebih kecil daripada pertumbuhan jumlah minimarket di Sidoarjo dan Gresik sebagai daerah pembanding. Hal ini kemungkinan karena minimarket pada umumnya membidik masyarakat kota sebagai konsumen. Di desa seperti di Pulau Madura, masyarakat pada umumnya membeli kebutuhan pokok mereka di pasar atau toko.

Jumlah hotel merupakan salah satu variabel dengan estimator yang tidak pernah signifikan. Hal ini berarti pembangunan Jembatan Suramadu tidak berdampak pada kenaikan jumlah hotel. Keberadaan hotel dapat menjadi indikator perkembangan sektor pariwisata di daerah. Tidak signifikannya estimator jumlah hotel menandakan bahwa tidak ada perkembangan yang signifikanpada sektor pariwisata setelah beberapa tahun pengoperasian jembatan Suramadu. Hal ini dapat menjadi pertimbangan bagi pemerintah maupun sektor swasta untuk mengoptimalkan potensi pariwisata daerah dengan memanfaatkan konektivitas yang terbangun dari pengoperasian jembatan suramadu.

Estimator untuk seluruh UKM kerajikan bernilai signifikan dan positif di TR8. Selain pada TR8, UKM kerajinan kain tenun bernilai signifikan dan positif di TR4. Estimator yang besar menandakan bahwa pertumbuhan UKM kain tenun cukup pesat di dua kabupaten terdampak utama, yaitu Kabupaten Bangkalan dan Kota Surabaya. UKM kerajinan kayu bernilai signifikan dan positif di TR6 dan TR7. Hal ini menandakan adanya pertumbuhan UKM kerajinan kayu baru di dua kabupaten paling timur pulau Madura, yaitu Kabupaten Pamekasan dan Sumenep. Selain UKM kerajinan kayu, estimator lain yang juga signifikan dan positif di TR7 adalah estimator UKM kerajinan kulit dan UKM kerajinan anyaman, gerabah dan keramik. Berdasarkan deskripsi di atas, dapat disimpulkan bahwa kabupaten di Madura yang paling banyak menikmati dampak berupa kenaikan jumlah UKM kerajinan adalah Kabupaten Sumenep.

Kemudian pada sektor ekonomi, estimator jumlah UKM kerajinan kayu dan UKM kerajinan anyaman, gerabah dan keramik bernilai positif dan signifikan di periphery. Pada core, hanya satu indikator ekonomi yang positif dan signifikan, yaitu jumlah minimarket. Seperti yang dijelaskan pada bagian sebelumnya, minimarket pada umumnya memang tumbuh di daerah kota yang masyarakatnya memiliki daya beli yang lebih tinggi, preferensi barang yang lebih banyak dan mobilitas yang tinggi.

\section{Kesimpulan dan Rekomendasi}

Pembangunan Jembatan Suramadu tidak secara signifikan berdampak pada pertumbuhan ekonomi di daerah terdampak yang didefinisikan dengan TR1 hingga TR5. Namun pembangunan Jembatan Suramadu berdampak signifikan pada pertumbuhan ekonomi di daerah core dan periphery. Pada estimasi di level desa, pembangunan Jembatan Suramadu secara signifikan berdampak positif terhadap pembangunan di sektor pendidikan, kesehatan dan ekonomi. pada sektor pendidikan, variabel yang cenderung memiliki estimator DID yang positif dan signifikan adalah jumlah sekolah swasta. Di sektor kesehatan, variabel yang cenderung 
memiliki estimator dampak yang positif dan signifikan adalah puskesmas, posyandu dan fasilitas bersalin seperti polindes dan praktik bidan. Sementara itu di sektor ekonomi, estimator DID yang cenderung positif dan signifikan adalah jumlah restoran, toko, UKM kerajinan kayu dan UKM kerajinan anyaman, gerabah dan keramik.

Dampak terhadap pembangunan sektoral di tingkat desa lebih banyak dirasakan oleh daerah periphery daripada daerah core. Hal ini mengindikasikan bahwa gaya sentrifugal lebih dominan terjadi sebagai akibat dari pembangunan infrastruktur yang menghubungkan daerah core dengan periphery. Artinya, pembangunan Jembatan Suramadu sudah sesuai dengan tujuan aslinya yaitu untuk mengurangi ketimpangan antar daerah dengan mendorong pembangunan di daerah periphery. Hasil ini juga mendukung penelitian sebelumnya oleh Meijers et al. (2012) dan Donaldson (2010) dan memperkaya literatur yang menemukan bahwa pembangunan infrastruktur transportasi yang mendukung interkonektivitas dapat lebih menguntungkan untuk daerah periphery.

Berdasarkan kesimpulan studi ini, terdapat beberapa area yang dapat dikembangkan melalui penerapan kebijakan pemerintah untuk mendorong dampak yang lebih signifikan di daerah Madura. Dari sisi potensi ekonomi, Madura memiliki banyak wisata yang mulai popular sehingga dapat mendukung pertumbuhan industri akomodasi atau perhotelan. Pembangunan Jembatan Suramadu seharusnya dapat mendukung integrasi kewilayahan sehingga dapat mempromosikan daya tarik pariwisata di Pulau Madura. Madura juga memiliki sentra produksi batik yang merupakan potensi untuk pengembangan UKM. Oleh karena itu, arah kebijakan pemerintah daerah kabupaten-kabupaten di Pulau Madura seharusnya dapat menarik investasi sekaligus memberdayakan ekonomi mikro melalui dukungan UKM. Apabila pengembangan industri perhotelan dan kepariwisataan tersebut dapat diintegrasikan dengan program pemberdayaan UKM melalui promosi produk UKM di hotel maupun tempat wisata, maka hal ini dapat turut berkontribusi untuk pertumbuhan ekonomi di daerah Madura.

Dari segi akademis, penelitian ini masih dapat dikembangkan lebih lanjut. Salah satunya melalui penggunaan data jumlah perusahaan sebagai outcome dampak dari pembangunan Jembatan Suramadu terhadap pertumbuhan industri di Pulau Madura. Aspek lain yang juga menarik untuk diteliti lebih lanjut adalah mengenai dampak terhadap pertumbuhan lapangan pekerjaan di Pulau Madura. Kemudian dari sisi mobilitas, penelitian selanjutnya dapat mempelajari lebih lanjut mengenai dampak pembangunan Jembatan Suramadu terhadap pergerakan manusia dan barang dari dan ke Pulau Madura untuk memperkaya referensi mengenai gaya yang timbul akibat dari interkonektivitas daerah core dan periphery.

\section{Referensi}

Banerjee, A., Duflo, E., \& Qian, N. (2020). On the road: Access to transportation infrastructure and economic growth in China. Journal of Development Economics, 145. https:// doi.org/10.1016/j.jdeveco.2020.102442

Donaldson, D. (2018). Railroads of the Raj: Estimating the impact of transportation infrastructure. American Economic Review, 108(4-5). https://doi.org/10.1257/aer.20101199

Gujarati, D. N., \& Porter, D. C. (2012). Dasar-Dasar Ekonometrika. Edisi kelima. Jakarta: Penerbit Salemba Empat.

Hidalgo, D., Pereira, L., Estupiñán, N., \& Jiménez, P. L. (2013). TransMilenio BRT system in Bogota, high performance and positive impact - Main results of an ex-post evaluation. $R e-$ 
search in Transportation Economics, 39(1). https://doi.org/10.1016/j.retrec.2012.06.005

Jensen-Butler, C., \& Madsen, B. (1996). Modelling the regional economic effects of the Danish great belt link. Papers in Regional Science, 75(1). https://doi.org/10.1007/ bf02406957

Knudsen, M. A., \& Rich, J. (2013). Ex post socio-economic assessment of the Oresund Bridge. Transport Policy, 27. https://doi.org/10.1016/j.tranpol.2012.12.002

Kozłowski, W. (2012). Model for Evaluation of the Economic-Social-Environmental Outcomes of Investments in Road Transport Infrastructure. Olsztyn Economic Journal, 7(1). https:// doi.org/10.31648/oej.3406

Krugman, P. (1998). What's new about the new economic geography? Oxford Review of Economic Policy, 14(2). https://doi.org/10.1093/oxrep/14.2.7

Mahmud, M., \& Sawada, Y. (2018). Infrastructure and well-being: employment effects of Jamuna bridge in Bangladesh. Journal of Development Effectiveness, 10(3). https://doi. org/10.1080/19439342.2018.1483415

Masahisa, F. (2011). Globalization and Spatial Economics in the Knowledge Era. https://www. rieti.go.jp/en/events/tenth-anniversary-seminar/11011801.html (diakses pada Oktober 2018).

Meijers, E., Hoekstra, J., Leijten, M., Louw, E., \& Spaans, M. (2012). Connecting the periphery: Distributive effects of new infrastructure. Journal of Transport Geography, 22. https://doi.org/10.1016/j.jtrangeo.2012.01.005

Perroux, F. (1950). Economic space: Theory and applications. Quarterly Journal of Economics, 64(1). https://doi.org/10.2307/1881960

Preston, J., \& Wall, G. (2008). The ex-ante and ex-post economic and social impacts of the introduction of high-speed trains in South East England. Planning Practice and Research, 23(3). https://doi.org/10.1080/02697450802423641

Solow, R. M. (1956). A contribution to the theory of economic growth. Quarterly Journal of Economics, 70(1). https://doi.org/10.2307/1884513

Swan, T. W. (1956). Economic Growth and Capital Accumulation. Economic Record, 32(2). https://doi.org/10.1111/j.1475-4932.1956.tb00434.x 